\title{
明治中期の未定稿からみた伊東忠太の日本建築研究 A STUDY ON CHUTA ITO'S UNFINISHED MANUSCRIPTS ON THE JAPANESE TRADITIONAL ARCHITECTURE IN THE MIDDLE OF MEIJI ERA
}

\author{
倉方俊輔* \\ Shunsuke KURAKATA
}

\begin{abstract}
This study deals with Chuta Ito's thought on the Japanese traditional architecture, who is known as the first Japanese architectural historian and critic. This paper treats 4 unfinished manuscripts in the middle of Meiji era.

As a result below mentioned 3 points become clear. 1) Before "Study on the Horyu-Ji" (1893), he tried to apply Western method to traditional knowledge on Japanese architecture. 2) In some draft, he showed unique concepts for Japanese architectural history. 3) He regarded his studys about curved line as the connection between the design and the standard.
\end{abstract}

Keywords : Chuta Ito, Meiji Era, Architectural History, Building Construction, Ornamental Design 伊東忠太、明治時代、建築史、建築構造、装飾デザイン

\section{1 はじめに}

本研究は、建築学者・建築家である伊東忠太（1867-1954）が 残した未定稿を分析し、初期の日本建築研究の性格について考察を 行う。対象とするのは、1892年9月に帝国大学大学院に進学してか ら、1902年3月にアジア・欧米留学に出発するまでの期間である。

この10年間は、伊東が最も質の高い論文を生産した時期として 知られる。単体の日本建築を扱った最初の論文である「法隆寺建築 論」を発表し（1893年）、改稿を経て学位請求論文（1898年）と して完成させた。「建築術と美術との関係」(1893年)や「『アーキ テクチュール』の本義を論じて其訳字を選定し我が造家学会の改名 を望む」(1894年）といった論考では、自らの建築概念の啓蒙を試 み、「日本建築術研究の必要及び其の研究の方針に就て」(1894年) や「国家は古建築物を保存すべし」(1895年) などを通して、日本 建築の研究と保存の必要性を訴えた。また、『日本帝国美術略史稿』 （1901年）の執筆を分担し、「日本神社建築の発達」（1901年）を 叙述して、日本建築通史の構築に大きな役割を果たした。

この期間に著述され、発表されないままに終わった未定稿として、 下記の 4 篇が確認される。

(1)「日本建築構造論」

(2)「大日本建築通誌」

(3)「曲線運用に関する実例に由て其定理を究む」

(4)「日本建築に於ける絵様の曲線の発達に就て」

これらは発表論文にない内容を持ちながら、それらに通底する性 格を内在させている。近代日本の建築思想、建築史学を毫引した伊 東の思考を理解する上で、検討する意義は大きいと考えられる”。 本研究では 4 篇の未定稿を、他資料とともに考察する。(1)から大
学院進学当初の日本建築に対する論じ方を、(2)から日本建築史通史 への試みを読み解く。(3)と(4)については、発表論文である「日本建 築に於ける曲線の性質を論ず」（1894-95年）と併せて、一連の曲 線論の意味を再考する2”。

\section{2 「日本建築構造論」}

\section{2-1 内容}

B5版無野紙9枚が綴じられた冊子と、B5版蓈線紙15枚が綴じら れた冊子の 2 冊がある。前者は「自序」(2枚)、「凡例」(1枚)、「総 目次」(2枚)、「緒論」(4枚) からなり、「日本建築構造論」という タイトルと「明治二十五年十二月 伊東忠太誌」という年記が認め られる3”。後者の内容は、前者の「総目次」に対応している。両者 は一続きの資料であり、明治25年 12 月までに成立した未定稿「日 本建築構造論」とみなすことができる。内容を検討したい。

「自序」によれば、本稿は「是を學理より得すして却て実際の経 験より得るもの」が多いために「互に相連環するの理法」を知らず、 「恰も闇黒界中に微光の散在するか如き」状態である「我か藝術」 に対して、「彼の微光を収拾し 終に以て惄然たる美光を発せしむ るの階梯たらん」ためにまとめられた。契機は、「其の昫眼を以て 普ねく我邦の文物を看破し小「今や彼は其迅速機敏なる観察を迋ふ し 本邦の藝術を探知し尽し將に亦た進んで我か建築及ひ建築装飾 の区域を侵さんと欲するに至」っている「欧米の學者」の動向であ る。「當局者は須く其双手を挙けて先つ本邦建築搆造の調査を遂け 彼の断扁片章を収拾し之をして一箇の完全なる一科學たらしめ〈中 略〉日本建築の精致を宇内に知らし」めなくてはいけない。こう記 して、本稿の意義が強調されている。 
「凡例」は、著作にあたり、「特に辰野金吾氏及ひ木子清敬の懇 篤なる掖導」を受け、「先進諸氏の口授と余の実験とを以て経緯」 としたと述べる。

「総目次」は、3篇 21 章と付録 3 章からなる構成を示す（表 1 )。 各章のタイトル下には、「L」を冠した1から 37 の数字が認められ る。欄外には「in $/ 37$ Lectures」という書込みがある。これらの 記載は、本稿が講義草稿としても考えられていたことを示唆する4。

「緒論」は、論文の方法と構成を説明する。まず、日本建築の「形 式の奇異」と「搆造法の精妙」を「萬国に見さる所」と称賛し、「日

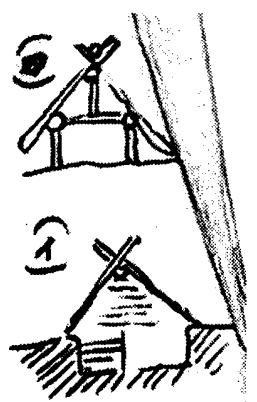

图 1 「日本建築搆造論」p.19

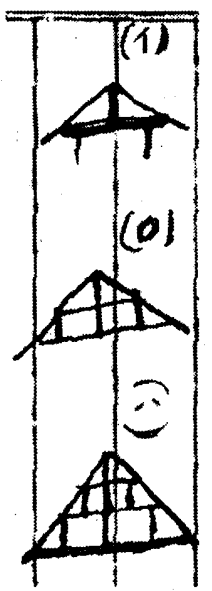

图 3 「日本建築搆造論」p.27

図 2 「日本建築搆造碖」p.19

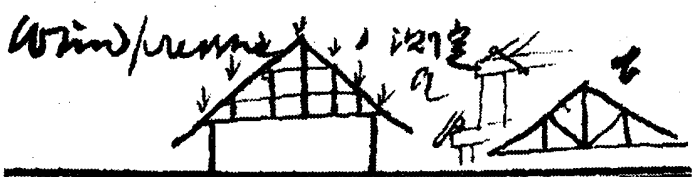

图4 「日本建留搳造論」p.38
本建築の搆造」を、仏教建築の伝来によって花開き、以来、発展し てきたものと捉える。これを大観するには「我か建築形式の歴史と 并ひ論するに非されは 未た其精緻を悉す事」ことはできない。し かし、「姑らく其煩雑を避けんか爲め」に「古代建築の不完全なる 搆造法」については「建築歴史の範囲内に䛊り」、今日行われてい る「本邦建築の標準と爲すに足るへき完良の搆造法」を説くとして、 論文の方法を定める。

構成については、「第一篇 構造原論」で「各種の建築に共通す へき数理上并ひに美術上の觀察」を行い、「第二篇 搆造細論」で は「本邦の完良なる住屋」を標準として、「実際上尤も必要なるも の」である「建築搆架の方法」を「建築工事の順序を追ひ 泰西搆 造論の系式を㽎酌」して詳説するという。ついで「第三篇 搆造例 証」では、各種建築に特有の「搆架の方法」を列記して「本邦建築 を爱に網羅」し、付録では「材料の性質 其撰擇の方法等を論し併 せて仕様計算及ひ実地施行の順序を附記」すると述べる。

「第一篇 構造原論」の第 $1 \sim 5$ 章に該当する未定稿が現存する。

「第一章 搆架式を論す」は、世界的な視点から日本建築の構造 形式の特徴を論じ、その優劣を指摘する。「何れの派流を問はす、 何れの形式に論なく、凡そ建築術は材料の搆架に由て成るものな り」という文章に始まり、原始的な「居住」(住居) が(イ)から(ハ) に進み（図 1)、「柱壁と屋蓋との相互の関係」によって「終に得く 幾多の形式を生する」過程を図示する(図 2)。「本邦建築の搆架式」 は、「第一回より進化して漸く第四回の形を成し終に肘木爲るに至 りたり」と位置づけられる。

日本建築の特徴は「東洋諸国は地味豊饒にして森林多く、好良な

表 1 「日本建築構造論」における「総目次」の記載

\begin{tabular}{|c|c|c|}
\hline \multirow{2}{*}{\multicolumn{3}{|c|}{$\begin{array}{c}\text { 日本建築搆造論 総目次 } \\
\text { 緒論 }\end{array}$}} \\
\hline & & \\
\hline \multicolumn{3}{|c|}{ 搆造原論 } \\
\hline 第一章 & 搆架式を論す & L l \\
\hline 第二章 & 衡度法を論す & $\mathrm{L} 2$ \\
\hline 第三章 & 木割の解 & L 3 \\
\hline 第四章 & 材料強䐞論 & L 4 \\
\hline 第五章 & 指口及ひ継手論 & L5 \\
\hline 第六章 & 「ヂテール」概論 & L 6 \\
\hline \multicolumn{3}{|c|}{ 搆造細説 } \\
\hline 第一章 & 基礎の搆造 & $\mathrm{L} 7$ \\
\hline 第二章 & 床下の搆造 & L 8 \\
\hline 第三章 & 間内の搆造 & L 9 \\
\hline 第四章 & 外部の搆造 & L 10 \\
\hline 第五章 & 軒廻りの搆造 & L 10-11 \\
\hline 第六章 & 小屋組及屋根の搆造 & L $12-13$ \\
\hline 第七章 & 屋根の搆造 & L $14-15$ \\
\hline \multicolumn{3}{|c|}{ 第八章一附説 實地建築の順序 } \\
\hline \multicolumn{3}{|c|}{ 第参編 搆造例証 } \\
\hline 第一章 & 神社 & L $16-17$ \\
\hline 第二章 & 仏寺 & L 18-19 \\
\hline 第三章 & 高塔 & L 20-21 \\
\hline 第四章 & 宮殿 & L 22-23 \\
\hline 第五章 & 住家 & L $24-25$ \\
\hline 第六章 & 茶室 & L $26-27$ \\
\hline 第七章 & 城堡 & L 28 \\
\hline \multicolumn{3}{|c|}{ 附録 建策材料概論 } \\
\hline \multicolumn{3}{|c|}{ 右三編二十一章别附録一章 } \\
\hline 第一章 & 建築材料概論 & L 29-31 \\
\hline 第二章 & 仕様及計算 & L 32-34 \\
\hline 第三章 & 実地施工法 & L 35-37 \\
\hline
\end{tabular}


る木材を産出する事極めて多き」ゆえに「迫持式」(アーチ構造) が存在せず、小屋組構造が「全く水平、鉛直」からなることだとし て（図 3)、次のように総括する。

本邦建築の搆架法は其木材の唯一の材料なるに由りて、終に古来[木+ 眉]式建築の発達を致し却て迫持式を現出せす、而して其骨格は常に水 平鉛直の二種の搆架より成り、屋蓋の傾斜を作るものを除くときは他 に斜線を作るもの無く、其小屋組の如きに至りても、亦た堅く彼の主 義を墨守するを見る、是故に之を重學に考皇るときは、材料の浪費は 免るへからさるの過失なりとす

続いて、日本建築構造の利を説く外国人の見解を列記する。「氏 の言は悉く信するに足らずと雖も」等としながらも、その論旨に賛 意を示し、先の総括に肯定的な評価を加える。

「第二章 衡度法を論す」と「第三章 木割の解」の記述は少な く、検討に値する内容は無い。

「第四章 材料強弱論」は、第一章の議論を引き継いで、小屋組 構造を中心に考察する。「若し保護の法にして完良ならば、木材は 猶ほ永く本邦建築に良資を与ふるものならんとす」として木材の使 用を是認し、「毫も数理的思想を含有せさるを以て〈中略〉巨材を 浪費する」木割を庰して、「木材の性質強弱等」の研究を進めるこ とを求める。小屋組構造に対しては、「其木材を浪費する事実に甚 しものあり、之を欧米の式に比較して及はさる事遠しとす」と結論 付け、「余は小屋丈けは洋式を採用せんと思ふ」とトラス小屋組の 採用を明言する（図4）。ただし、震災にあっては、変形を許さな いトラス小屋組より、ある程度まで変形しても持ちこたえる和小屋 組のほうが強いという見解を示している゙。

「第五章 指口及継手」は、日本建築の継手仕口を検討する。必

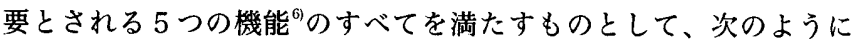
称賛し、機能による分類”を試みたところで未定稿は終わる。

多年の経験と材料の唯一の木材なるより驚くへき発達を致したり、而 して其テンション、コンプレション等のカの種類に随ひて其適當の法 方を誤らさる事と、その細工の精工巧妙なるとは実に世界中に其比を

見さるへし、従来の方則に對しては吾人は毫も非難する所あらず

現存する本文の内容は、世界建築の中に日本建築の構造を位置づ けようと試み、主に材料の効率と耐震性から、(1)今後の木材の使 用を是認し、(2)条件付きながら和小屋組に代わるトラス小屋組の 採用を主張し、(3)伝統的な継手仕口を評価したものとして、まと められる。

\section{2-2 考察}

本稿は、伊東にとって初めて、日本建築を具体的に主題とした論 考として注目に值する。同年 7 月に提出された卒業論文「建築哲学」 は、西洋建築の理解を背景に将来の様式を理念的に論じることを主 眼としており、日本建築は直接の研究対象になっていない。翌年11 月の「法隆寺建築論」以前の論考も同様である。「建築哲学」には、 本邦建築の「未来を知らんと欲せば必ずや先づ其過去を知ら」ねば ならないという意志が示されている。時間的には、本稿がこれを実 行に移し、「法隆寺建築論」との橋渡しになったと捉えられる。

しかし、考えなければならないのは、1 年にも満たない間に記さ れた2つの日本建築論の内容が大きく異なるという事実である。法 隆寺建築論」が、古代の日本建築を主に意庍的側面から扱って特殊
特殊性を論じたのに対し、本稿は近世から連続する構造法を一般的 に論じている。「法隆寺建築論」における木割の否定や「搆架式」 の節の存在に連続性が感じられるが、対象や方法は対照的である。

こうした本稿の性格は、以後の伊東の活動と比べても異質といえ る。当時、帝国大学では木子清敬が講師として「日本建築学」を教 えていた。木子に要求されたものは日本建築史ではなく、現在まで 連続する「日本建築学」であり、建築の設計あるいは分析理論に相 当する木割や、標準設計資料に該当する雊形に重きが置かれた 本稿はむしろ、こうした木子の実践的性格に近い。

もう一つの特徴は、外国人研究者に対する反発と援用が併存して いる点である。「自序」に対抗意識が明らかだが、一方では、第 1 章においてジェームス・ファーガソン、エドワード・モース、クリ ストファー・ドレッサー9'が日本建築の耐震性について述べた言葉 を引き、論拠としている。モースからの影響は、とりわけ顕著であ る。彼が『日本人の住まい』 ${ }^{10} て ゙$ 示した見解は、第 4 章でも引用さ れており（継手仕口に対する見解で、これには否定的である） ${ }^{11 !}$ 、 先のジェームス・ファーガソンの主張も同書から孫引きした可能性 が高い ${ }^{22}$ 。外国人の見解の直接的な参照は「法隆寺建築論」以降、 ほとんど行われなくなる。この点においても、本稿は、日本建築を 対象としながら、「法隆寺建築論」よりも「建築哲学」に近い性格 を持つといえよう。モースらの日本建築論に強く触発され、その手 法を取り入れつつ、対抗するという意志が前面に出ている。

本稿は、実践的な性格を併せ持つ木子清敬の「日本建築学」を継 承し、西洋的な分析手法の適用を試みたものといえる。「断扁片章 を収拾し之をして一箇の完全なる一科學たらしめ」るという「自序」 の言葉が、「近代＝西洋」によって「近世」を革新しようという意 図を物語っている。

こうした取組みは、当時の帝国大学造家学科に求められた実践的 性格にふさわしいものである。木子と共に、伊東の大学院での指導 教官であった辰野金吾から、直接的な指示があったことも想像され る ${ }^{13)}$ 。しかし、「法隆寺建築論」との隔たりを外的要因だけに還元 することはできないだろう。先に触れたように卒業論文「建築哲学」 は歴史の論考ではなかった。理念的性格が強いとはいえ、結論は現 在への明示的な提言となっている。本稿と同時期に書かれた「本邦 建築術未来の運命」 ${ }^{14)}$ も同様である。大学院に進学した当初、伊東 の専攻は「日本建築」であり、「日本建築史」の探求に狙いを定め ていたわけではない ${ }^{15\rangle}$ 。本稿は、「法隆寺建築論」をまとめる以前 における、伊東の「日本建築学」に対する取組みを示す。内容は「日

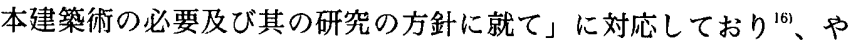
や脈絡を欠くように思われていた同論の位置を明らかにする。

「法隆寺建築論」との関係として指摘できるのは、両者の内容が 対照的であることによる影響である。「古代建築の搆造法は之を建 築歴史の範囲内に譲」ると明言していることは、本稿の執筆が、近 世から連続する実践性を持った日本建築認識、あるいは西洋人研究 者による日本建築の把握の外部にある「法隆寺」の意味合いを、強 く意識させたことをうかがわせる。

\section{3「大日本建築通誌」}

\section{3-1 内容}

B5版野線紙5枚が綴じられており、「明治二十八年／大日本建築 
通誌 巻之一/大學院學生 伊東忠太」と表紙にある。2 枚目の「緒 言」に記入は無く、それに代わって1〜2枚目の野線上部に「序」 と題した断章が残る。3〜 5 枚目に「第壱篇. 佛寺建築」の一部を 記し、稿は中断する。

「序」（表 2）の記述は、注目に值する。従来欠けていた日本建 築に対する秩序的な「学術」の確立を主張（1～7）した後に、対 象をひとまず仏教寺院に限定し（8）、建築を論じる上での歷史的 視点の必要性を述べている $(9 \sim 10)$ 。以上の部分は、「日本建築構 造論」の方法的な主張にほぼ等しい。

以後の内容は、より独自性が強い。一般史（11）や宗旨 (12) による論を退けて、建築そのものが時代区分を持つ（13～15)。し かし、その詳細は中国建築研究が進展した後でなくては論じられな いがゆえに（16）、本稿では歴史ではなく、一般的な建築形式を主 とすると述べる $(17 \sim 19)$ 。建築そのものから帰納して、過去の日 本建築を叙述しようという意志が、ここに示されている。

「第壱篇 佛寺建築」の現存部分は、ほぼ対象の分類に終始して いる。「我邦建築の泰斗」である「仏寺建築」の「学術的の分類法 の如きは実に非常なる難事に属す」としながらも、「姑らく余の偏 見を以て」4つに分ける（表 3 )。このうち、第一の「堂」は「其 範囲尤も廣大」であり、「建築物の性質及名称に從て」並べると際 限が無いとして、「外部の形式に依りて」、首建築」と「單層建 築」の二種に区分する。さらにその構造から「二層建築」の中に「第 一類 上層入り母屋高欄付、腰屋根」の節を置く。構造について記 述されているのは、この最初の節のみである。「推古建築」(飛鳥様 式）を扱い、法隆寺金堂を「意匠縦横到らさる所なし、其手法勁強 簡潔にして繪画彫刻の装飾を用みす、然も能く全体の衡度を得て姿

\section{表 2 「大日本建築通誌」における「序」の断章}

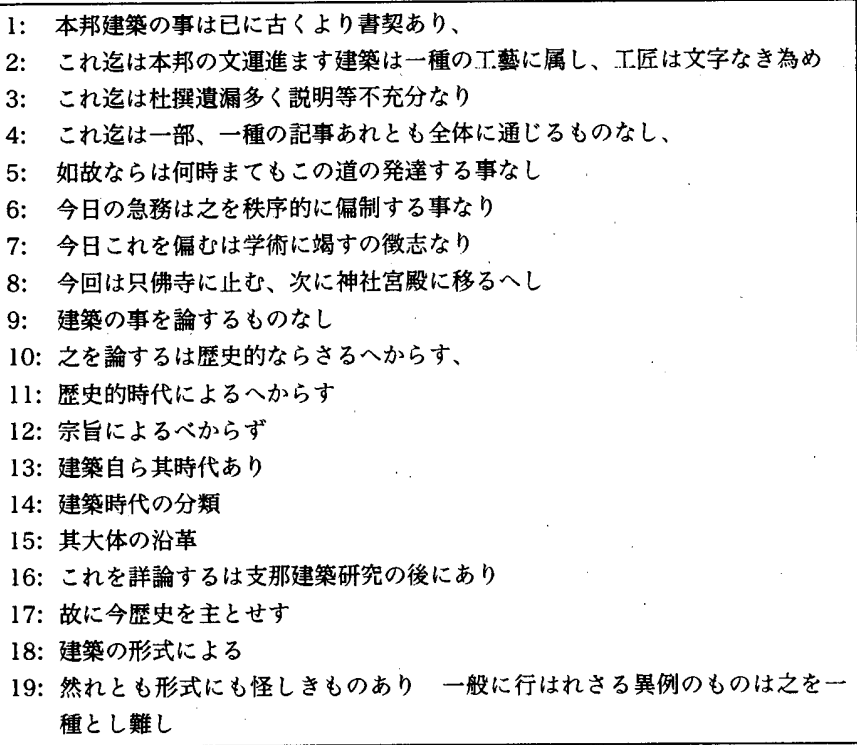
※冒頭の番号は説明のために付加した

表 3 「大日本建築通誈」における仏寺建築の分類

\begin{tabular}{|l|l|}
\hline \multicolumn{1}{|c|}{ 分類 } & \multicolumn{1}{|c|}{ 説明文 } \\
\hline 堂 & 金堂、講堂、食堂、戒壇堂、鼓樓、鐘楼、東、西、南或は北円堂 \\
\hline 塔 & 各層のもの \\
\hline 門 & 大門中門等 \\
\hline 附属建築 & 方丈、庫車及塔中の各院 \\
\hline
\end{tabular}

勢の優輪魚の美多く後世に其儔を見」ないと称賛する。優良である 理由は「推古の朝 本邦の人文猶ほ甚た幼稚」であり、「堂宇の建築 は一に之を韓土の工匠に委」ねたことに求められている。

\section{3-2 考察}

本稿は断片的なものだが、日本建築通史を完成させる以前の伊東 が、過去の日本建築を、より、(1)原理的・内在的に、かつ、(2)大 陸の建築との梁い関係のもとで、捉えようとしていたことを示す。

日本建築通史として最初に完成したのは、1901年に刊行された 『日本帝国美術略史稿』 ${ }^{17}$ の建築部分である。美術通史の一部とい うこともあり、美術史の時代区分にしたがって、年代順に叙述して いる。通史的記述の最初は、1897年に書かれた「本邦仏教各宗の 建築」(8)である。奈良朝、平安朝、鎌倉以降に分けて、宗派ごとに 叙述している、

しかし、1895年に記した本稿では、こうした「歴史的時代」や 「宗旨」による記述が否定され、「支那建築研究」が整わない現段 階での次善の策として、「建築の形式」にしたがった分類が試みら れている。ここでいう「形式」は、残された内容をみる限り、「日 本建築構造論」で「構造」とされていたものに近い。構造形式に対 する大学院入学当初の関心を引き継ぎ、それを現在ではなく、過去 の日本建築を記述する指標としたことが分かる。

2 年後の「本邦仏教各宗の建築」において、伊東は「宗教建築な るものは素と教旨を代表するに足るへきの輪奐を備へ、其儀式祭典 等を挙行するに適すへき配置を有すへきを以て宗教の変遷は必す常 に其建築の変遷を致ざるるは無きなり」と記した。建築の形態を成 立させる要因として、「宗旨」が捉え直されている。建築をその成 立要因から解釈しょうという「建築哲学」の指向は、本稿を経て、

「本邦仏教各宗の建築」に形を変えて連続している。

外形的な記述ではなく、建築独自の原理にしたがって叙述するこ と、および、一国史的にではなく、諸外国との関連を含めて論じる ことは、建築種別によって解説していた木子清敬や黒川真頼らの既 往の記述を乗り越えようとしたものと認められる ${ }^{199}$ こうした方法 論は『日本帝国美術略史稿』で貫徹されたとはいえないし、その後、 改めて日本建築の通史が書かれることもなかった。抏そらくは、そ の課題の大きさと、アジア・欧米留学以降の活動領域の拡大のため に、本稿に現われた目標は、別の形で追求されたと考えられる。

\section{4 一連の曲線論}

4-1「曲線運用に関する実例に由て其定理を究む」の内容

B5版䀧線紙12枚からなり、「曲線運用に関する実例に由て 其定 理を究む／大學院學生 工學士 伊東忠太」と冒頭に記されている。

「緒言」の他に 4 章が認められるが、半数以上のページは白紙か小 見出ししか記されておらず、内容は断片的なものになっている。

「緒言」は、本稿が「日本建築に於ける曲線の性質を論ず」 ${ }^{201 の ~}$ 続編であることを示す。「尔来余は専心其研究に従事し、務めて材 料を蒐集し、幾多の実例に就て真理の在る所を努めん事を企図し た」。その結果として、「研究の結果を列挙し以て余か自ら定理と信 する所を陳述」すると述べる。

「第一章 第一種の曲線」は、日本建築における円周の適用を「千 鳥破風」、屋根流扎、「切妻破風」等に則して考察する。その目的 
は「形状の円周より成れるものは決して円満なる美観を呈する事を 得さる事」を示すことにある。具体例においては、古代建築の「美」 と近世建築の「醜」を対比的に捉える傾向が強い ${ }^{211}$ 。

「第二章 第二種の曲線」には、まとまった文章が存在しない。 この章で考察を予定していた対象として、「肘木」、斗繰」、「尾垂 木及垂木、附隅木小「勾欄架木、棟」「李負、茅負、裹甲」、「虹 梁」が列記されている。

「第三章 第三種の曲線」にも、「唐破風」「海老虹梁」、蟇股」、 「四葉五葉及六葉」といった名称のみが並ぶ。唯一、本文を持つの は「懸魚」の個所だが、「其他この課題中に於て説くへきもの」と して「所謂油煙形、宝珠形、洲濱形、火燈形、雲形」や「拳鼻の如 き彫刻の性質を具有するもの」を挙げ、「事の浩瀚に失する事を恐 れ之を他日に譲りて姑く茲に筆を擱く」と記すにとどまる。

「第四章 結論」の闌外に、五か条の断章が残されている。

一 円周の不美

一 結果的に標準とするもこれを直写せさる事

一 直曲の接続分からぬ事 実は曲線斗りなるへき事

一 インフレキションの点の分ら好事

一曲率は小なるを貴ふ

日本建築の実例を引き、曲率を微妙に変化させながら連続する曲 線を、最良のものとして結論づけたかったと推定される。

\section{4-2 「日本建築に於ける絵様の曲線の発達に就て」の内容}

B5版睪線紙13枚からなり、「日本建築に於ける絵様の曲線の発達 に就て」と冒頭に記されている。「緒言」の他に 3 章が認められる。 文章は断片的ではあるが、検討に値する図版に富み、先の論文に比 べて充実した内容を持つ。

「緒言」は、主題である「絵様」を「廣義に於ては建築の平面な る部分の上に施せる曲線形の形象若くは建築に附加する平面的の曲 線形象」と定義する。本稿における「絵様」が、細部意匠の輪郭線 なども含む幅広いものであることが分かる。「元来日本建築は所諳

\section{表 4 「日本建築に於ける絵様の曲線の発達に就て」 における「絵様」の分類}

\begin{tabular}{|c|c|c|}
\hline 装飾的 & $\begin{array}{l}\text { 附加物 } \cdots \cdots \cdots \\
\text { 平面上に施すもの }\end{array}$ & $\begin{array}{l}\text { (慗魚の類) } \\
\text { (格狭間の類) }\end{array}$ \\
\hline 構造的 & $\begin{array}{l}\text { ビームに施すもの } \\
\text { 構造的のもの }\end{array}$ & $\begin{array}{l}\text { （海老虹梁の類） } \\
\text { (かへるまたの類) }\end{array}$ \\
\hline
\end{tabular}

表 5 「日本建築に於ける絵様の曲線の発達に就て」における線条の分類

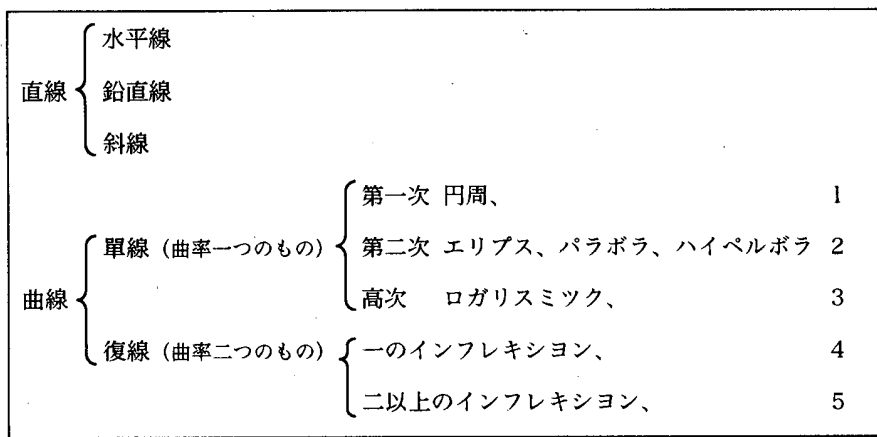

搆造的誠実なるものなるか故にこれ絵様を施して美を致すは恂に適 当」だとして、その使用は称賛されている。「絵様の一般の性質と 其変遷の梗概のみを述ふる」とし、構造的役割の有無と付加性に応 じて 4 つに区分する（表 4$)^{22) 。 ~}$

「第一章 曲線の分類及其運用」では、日本建築の細部意匠につ いて、曲線の要素を符号で表現し、互いの類似関係を例示し、一般 的な規則を提出している。

まず、線条を分類し、曲線の種類に 1 ～5の符号を与える (表 5 )。 5 については「多く用みられさるを以て畧」し、1〜4の組み合わ せで生まれる10通りの曲線が、日本建築の細部意匠を構成してい ることを図解する(図 5 )。

続いて、「繪様に實用せらる、曲線は其種類多しと雖とも子細に 観察するときは一定の法規ありて〈中略〉全一種のものを種々なる 方法に由て種々に転用す」として、蟇股、懸魚、拳鼻（木鼻）、格 狭間、八双 (八双金物) を五角形の頂点に置いて対角線をつなぎ、 互いを結んでできる10通りの直線に該当した具体例を挙げる。猪 目形と火燈空の類似や、宝珠形のヴァリエーションも示している。 一般的な規則として、「変化あり全く全しものを反復すへからす」、 「無意味なるべからさる事」「写生的なるべからざる事」を記す。

「第二章 曲線の変遷」は、日本建築の曲線の変遷を歴史的に捉 え、「萌芽時代」(奈良～平安時代)、「発達時代」（鎌倉～室町時代)、 「興隆時代」(桃山時代)、「墮落時代」(江户時代）の 4 期に分類し (表 6 )、図を交えながら説明する。時代が下るにつれて「絵様」

\begin{tabular}{|c|c|c|}
\hline 符号 & 図形 & 曲線の種類 \\
\hline 1 & & 曲率が一定のもの \\
\hline 2 & v & 曲率が変化するもの \\
\hline 3 & & 対数曲線 \\
\hline 4 & 6 & 変曲点を持つもの \\
\hline 5 & & 変曲点を複数持つもの \\
\hline
\end{tabular}

\begin{tabular}{|c|c|c|}
\hline 符号 & 図形 & 細部意匠 \\
\hline $1 \& 1$ & & 奬魚 \\
\hline $1 \& 2$ & & 奬魚 \\
\hline $1 \& 3$ & & 格狭間 \\
\hline $1 \& 4$ & & 蟇股、拳鼻 \\
\hline $2 \& 2$ & & 格狭間 \\
\hline $2 \& 3$ & & 拳鼻 \\
\hline $2 \& 4$ & & 唐破風 \\
\hline $3 \& 3$ & & 唐破風の鮨 \\
\hline $3 \& 4$ & & 拳鼻 \\
\hline $4 \& 4$ & & 火燈、猪目 \\
\hline
\end{tabular}

図 5 「日本建築に於ける絵様の曲線の発達に就て」における曲線の分類 
様」が增加し、質が落ちると主張する ${ }^{23}$ 。

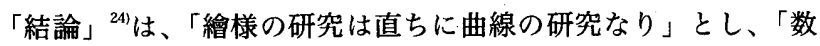
学的研究」の重要性を説く。

\section{4-3 考察}

2 篇の未定稿が、1894〜95年に発表された「日本建築に於ける 曲線の性質を論ず」の続編であることは明らかである。同論は、数 学的曲線を正しく応用することで美が得られるという立場から、曲 線を「第一種 曲率一定なるもの、第二種 曲率に変化あるもの」、 「第三種 反対曲率なるもの」に大別し、日本建築への応用例を図 と共に示した。

「曲線運用に関する実例に由て其定理を究む」は、この構成を引 き継いでいる。記述は断片的で、成立年も特定できないが、新たに 具体的な建築名称が挙げられていることは、論としての発展を表す。

「日本建築に於ける絵様の曲線の発達に就て」は、新たに歴史的 な検討を行なっている ${ }^{25)}$ 。これは「曲線活用の起源及び進化を論す るは則ち之を他日に譲らん」（「日本建築に於ける曲線の性質を論 ず」結尾）という記述に対応する。図 5 と極めて類似した内容が、 1901年に記された野帳にみられることから ${ }^{26)}$ 、成立はこの頃と推 定される。最初の曲線論からの7年間に、伊東は古社寺保存会委員 として全国に出張を繰り返した。その中で、多くの細部意匠を野帳

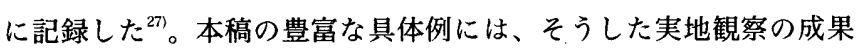
が反映されている。同時に曲線の分類をさらに推し進め、伊東の曲 線論が当初から持っていた数学的な性格をより強めたものでもある。 採集した個別事例を数学的な法則で統括しょうという未定稿の存在 は、多様性への関心と一般的法則の追及が、伊東の中で表裏一体で あったことを示す。

伊東が曲線論に関心を持ち続け、その展開を試みていたことが新 たに判明した。美の中に数学的な法則性を追及するという点におい て、これはオーウェン・ジョーンズの『装飾の文法』を彷彿とさ せる。同書は、伊東が大学 2 年の 1 学期にジョザイア・コンドルに 学んだ「装飾法」で教科書的な役割を果たしており

\section{表 6 「日本建築に於ける絵様の曲線の発達に就て」における時代区分}

\begin{tabular}{|c|c|c|}
\hline 呼称 & 年代 & 評価 \\
\hline 萌芽時代 & $\begin{array}{l}\text { 奈良朝より } \\
\text { 平安朝の終まで }\end{array}$ & 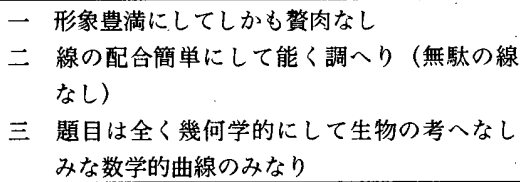 \\
\hline 発達時代 & 鎌會 足利時代 & $\begin{array}{l}\text { 一 線は細く強くして高次の曲線なる事 } \\
\text { 二 形は清瘦にして䝷肉なき事 } \\
\text { 三 線の配合は自在にしてカプスの鋭利なる事 } \\
\text { 四 題目に写生的の意味少き事 }\end{array}$ \\
\hline 興隆時代 & 豊臣時代 & 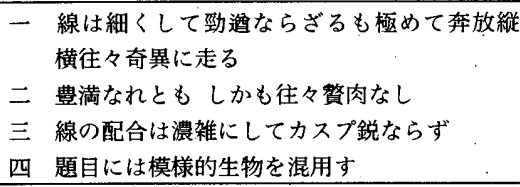 \\
\hline 堕落時代 & 徳川 & 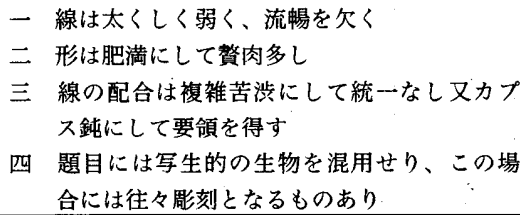 \\
\hline
\end{tabular}

の参考文献にも挙げられている。ここから着想の一つを得たと考え られる。

曲線に対する言及は、これ以外の論考にも広く見られる。美的に 曲線を直線よりも高尚なものとし、太古には直線だけであった装飾 や建築が次第に複雑な曲線の使用に至るという歴史認識は、大学 1 年の時に執筆した「美術起源考」 ${ }^{300}$ から、1901年の『日本帝国美 術略史稿』 ${ }^{31}$ まで連続する。「建築哲学」で「『ウイオレー』氏は建 築術は則はち繰形なりと云ひ『チエンバー』氏か繰形は国人美術的 思想を判断するの鍵なりと云ひしも亦た過言には非ざるなり」 ${ }^{327}$ と いう見解を取り上げている点には、細部曲線と各国様式を関連づけ る思想の萌芽がうかがえる。「法隆寺建築論」ではエンダシスが「数 學の所謂コンコイド、オフ。ニコ子ーツ」であると述べ33!、改稿か らは秤肘木の曲線の分析を追加した ${ }^{34)}$ 。平安神宮の解説である「京 都記念殿建築談」においては、絵様や懸魚の時代的変遷を曲線の変 化として論じている ${ }^{35}$ 。

曲線への関心は、終局的には生来の好みに還元される に対する継続的な取り組みは、そうした美的な㖺好と、一般的法則 を追い求める学問的な喈好 ${ }^{377}$ を接続するものであることによる。よ り幅広い曲線への言及からは、それが世界の建築の共通性と差異を 理解するという関心に通じていたことが分かる。留学以降、曲線論 の展開は影を潜める。一般的法則の追及は主に「建築進化論」に引 き継がれ、曲線によって各種の様式を結ぶという考え方は、設計活 動に表現の場を得たのではないかと推測されるが影、これについて は別稿を用意したい。

\section{5 おわりに}

本研究から以下のことが明らかになった。

初めて日本建築を具体的に主題とした未定稿として、1892年の「日 本建築構造論」がある。同論は翌年の「法隆寺建築論」と対照的な 性格を持ち、外国人研究者に対する反発と援用が併存している。内 容は「法隆寺建築論」以前の「日本建築学」への取組みを示すもの であり、この経験が「法隆寺」の意義を再認識させたと推定される。 1895年の「大日本建築通誌」は、日本建築通史を完成させる以前 の伊東が、過去の日本建築を、より、(1)原理的・内在的に、かつ、 (2)大陸の建築との深い関係のもとで、捉えようとしていたことを 示す。既往の歴史叙法の乗り越えを目指したものと考えられる。

1894年から1901年にかけて、伊東は独自の曲線論を展開させてい た。それは、美的な箸好と学問的な嗜好を接続し、世界の建築の共 通性と差異を理解しょうとするものと捉えられ、多様性への関心と 一般的法則の追及が、彼の中で表裏一体であったことを示している。

註

1) 未定稿はいず扎も東京大学建築学科所蔵。(2)は青木祐介「日本建築史・通 史の成立々伊東忠太」（伊東忠太未発表資料特別研究委員会報告会「伊東 忠太、その人と業績」第4回、日本建築学会、1999年6月5日)、(1)は清水重 敦「伊東忠太、1890年代 一保存・人脈・建築論一」(同報告会第5回、1999 年10月23日）によって初めて紹介さ机た。青木は併せて草稿「日本建築史 稿」を取り上げたが、r日本帝国美術略史稿」の決定稿とほほ同内容であ るため、本研究では対象外とした。

2) 伊東の初期の建築理念を総合的に検証した既往研究として、丸山茂の $\mathrm{r}$ 日 本の建築と思想 - 伊東忠太小論」(同文書院、1996) がある。卒業論文 である「建築哲学」を詳細に検討し、「法隆寺建築論」の内容変化を軸に、 
「学」と「国家」と「美」の関係の変遷を跡付けている。

3）「自序」の末尾に「明治二十五年十二月 伊東忠太誌」「凡例」の末尾に 「明治二十五年十二月 伊東忠太再誌、「総目次」の冒頭に「日本建築構 造論」「緒論」の冒頭に「日本建築搆造論／工學士 伊東忠太著述」と記 されている。

4)書き入れの残りは「55.5 Hours/in 37 Weeks／begun 15/9/ended 30/6」。 伊東が東京美術学校における「建築装飾術」の講義を正式に嘱託したのは 1893年2月だが、伊東の日記「浮世の旅」(日本建築学会蔵) や原安民ノ一 卜（東京芸術大学蔵）から、それ以前の1892年12月に講義を開始したこと が分かる。しかし、内容が「日本建築構造論」と大きく隔たっていること から、これが該当するとは考えにくい。帝国大学において、伊東が日本建 築史の講義を受け持つのは1897年以降であり、1901年までは講師の木子清 敬が日本建築学を教えていた。書き入㣗は後補の可能性もあるが、それ以 前に、伊東が日本建筑学を教える計画があったことを推測させる。

5)「震災に関しては(a)は『フレキシブル」なるを以て大に強しとす、(b)は 三角より成る、三角は『デフォーム」する事能はさるの形なり、強震に 逢へは必す崩る、四角は・デフォーム』すれとも重心の搆区外に出るまて

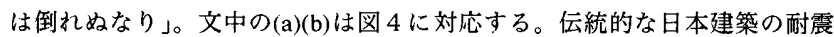
性については、この他、「第五章 指口及継手」において、「完全なる日本 搆造は木を接し又は継きたるものにて殆んと釘又は金物の力を假る事なし、 将にストラクチユアか、アュニフォーム」なり、金物の力を假るは存外に よき事に非す、此点に向ては地震に對して甚た堅牢なるものなりとす」と いう見解が示されれている。いずれも、その後、佐野利器らによって定式化 される木造耐震化の方向性とは異なり、当時の建築関係者の認識の一端を 示すと考えられる。

6) 1:「接續の面をして壓力の方向に直角ならしむる」、2:「可成材料を弱め ざる」3:「継手の各部をして能く重學的最大の『ストレス』に堪ゆへき か如く配布する」、4:「材料をして成可的些少の短縮と膨張とを受けしむ る小5:「外部の壓力をして可成均一に材料の裁断面に普及せしむる」。

7)「真水氏は部分に従て分ちた㣗とも不完全なり、又形に随て分つ事も出来 ない」と記し、張力に抗するもの（蟻継ぎ、鎌継ぎ、金輪継、箱継ぎ）と 圧力に抗するもの（割継ぎ、ほぞ差）、あるいは、補助部（目違い、入輪） や補足部（車知栓、吸付き、楔）といったように、機能による継手仕口の 分類を試みている。

8) 稲葉信子『木子清敬と明治 20 年代の日本建築学に関する研究一近代日本に おける建築の伝統の継承と展開の過程」(東京工業大学学位論文、1989)。

9) Christopher Dresser, Japan, Its Architecture, Art and Art Manufactures, Longmans, Green, \& Co., 1882

10) Edward Sylvester Morse, Japanese Homes and Their Surroundings, Ticknor \& Co., 1886. E.S.モース、斎藤正二・藤本周一訳 $\mathbf{P}$ 日本人の住まい』（八坂書 房、2000)。

11) 第1 章においては「モールス氏小第 4 章では「「モーレー」氏」と表記 さ扟ている。どちらもモース前揭書の引用であることは、内容から明らか である。

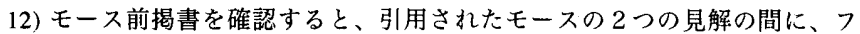
アーガソンの見解が引かれている。ただし、伊東がファーガソンの著書に 目を通していたことは「建築哲学」の参考文献から明らかである。

13）日記「浮世の旅」によれば、伊東は1892年12月に辰野に日本建築研究の 報告書を提出しており、本稿がこれに該当する可能性が高い。また、「大 日本建築通誌」で参照したドレッサー（前揭註9）とモース（前揭註10） の著作は、5か月前に提出した「建築哲学」の参考文献にも文中の引用書 にも見当たらない。本文において「搆造」という問題設定がやや唐突に現 れていることと併せ、主題に関して辰野など帝国大学関係者からの示唆が あったことが想像される。講義草稿をうかがわせる書き込み（註4）も傍 証となるだろう。

14) 伊東忠太「本邦建築術未来の運命」(「工学会誌」第132号、1892年12月)。 15) 日記「浮世の旅」の1892年7月略記の中に「前途の方針定まる」と題して、

「余は此れより大学院に入院して日本建築を尃修せん」と記している。

16) 伊東忠太「日本建築術の必要及び其の研究の方針に就て」(「建築雑誌」 第92号、1894年8月)。冒頭に記された外国人研究者の活動に対する対抗意 識や、「日本建築構造」の科目説明が特に類似する。

17）帝国博物館編篹「日本帝国美術略史稿」(農商務省、1901）。

18）伊東忠太「本邦仏教各宗の建築」(「建築雑誌」第126号、1897年6月)。
19）前掲註8。青木鿆介「明治11年出版の「工芸志料」における建築の分類に ついて」( $\boldsymbol{F}$ 日本建築学会学術講演梗概集F-2」1997年9月、pp.89-90)。

20) 伊東忠太「日本建築に於ける曲線の性質を論ず」(「建筑雑誌」第93.95. $98 \cdot 104$ 号、1894年9月-95年8月)。

21) 屋根反りについて、法隆寺夢殿や興福寺北円堂のものが「第一種の曲線 を脱して第二種に進める」称賛すべき形態をなしているのに対して、興福 寺南円堂等は「曲率寧ろ過大なるの队周を画き」、「其醜を暴露し来る」と 評する。また、高欄に於ける斗束の繰形は「往々円周より成る」が、「古 代に於けるものは却て松円に類する曲線より成」り、「其輪郭之か為めに 一種の気韻を添ふることを観察すへし」として、両者を図示する。

22）「又この内二以上を兼子たるもあり、拳鼻の如きは複雑なるものに在て は立体的の形象をなす、この場合には正当に彫刻の部類に入るものなり」 と付記する。

23) 桃山時代と徳川時代を一括して「阷落時代」とした一覧表も章の冒頭に 見られる。桃山時代部分は特に校正が多く、例えば、「意匠は奇巧にして 形状秀美よく其所を得たるもの多し」から「意匠は奇巧にして然れとも往々 其所を失へり」に、あるいは「線の配合は軽妙にしてカスプ鋭ならざるも 要領を得たり」から「線の配合は濃雑にしてカスプ鋭ならず」といったよ うに書き改めている。伊東の中で、桃山時代の建築に対する評価が摇扎動 いていたことが分かる。

24）当初、「第一章 曲線の分類」「第二章 曲線の運用」としていたもの を「第一章 曲線の分類及其運用」に改めたため、原文には「第四章 結 論」と記されている。

25)「明治廿八年十一月起稿／伊東忠太／日本建築術に於ける曲線の歴史的 発達を論ず」と記された、未定稿と同大の羁線紙 1 枚が残されており、よ り早くからの取り組みをうかがわせる。ただし、存在するのは表紙のみで、 原稿があったかどうかは不明である。同種の史料に、「明治二十九年三月 起稿／伊東忠太／日本建築術に於ける彫刻の変遷を論す」とだけ書か㧈た 罫線紙 1 枚がある。

26) 野帳 35 に所収。1901年 5 月の愛知県出張記録と、同年7 8月の夏期調査 旅行の予定表（紫禁城調查のために実現せず）に挟ま机ていることから、 1901年5 6月の記載と推定される。

27) 細部意匠のスケッ千は、1899〜1901年にかけて使用された野帳33・35に 特に目立って現れている。曲線論とのつながり、あるいは両者と関連した 思考的推移の存在を示唆する。

28) Owen Jones, The Grammar of Ornament, Day and Son, 1856.

29) 伊東忠太受講ノート（東京大学建築学科蔵）より。同史料については別 稿で報告を予定している。

30) 伊東忠太「美術起源考」第4回（『有為会雑誌」第5号、1890年5月）。

31) 前掲註 17。

32) 伊東忠太「建築哲学」(東京大学蔵、1892) p.189。

33）伊東忠太「法隆寺建築論」[初稿]（建築雑誌」第83号、1893年11月）p.331。 34) 伊東忠太「法隆寺建築論」[改稿］(『考古学会雑誌」第1-8号、1896年12 月-97年7月)、同 [最終稿］(東京帝国大学紀要」第1冊第1号、1898年3月)。 35) 木子清敬 - 伊東忠太「京都記念殿建築談」第 3 回 (『建築雑誌, 第87号、 1894年3月)。

36) 設計作品や戯画などに見て取れる。外国語学校在学中の1884年に描いた 美人画（東京大学建築学科蔵）から、こ扎が建築の専門教育を受ける以前 からの嗜好であることが分かる。

37) 初期のものとしては大学 1 年の時に記した「天運循環妙論」(『有為会雑 誌』首号・第1・3・4・6号。1889年12月-90年6月）が挙げられる。共に伊東が 希求する〈一般的法則〉と〈美的な自由〉の緊張関係は「建筑進化の原則 より見たる我邦建築の前途」(『建築雑誌」265号、1909年1月) に顕著に現 れている。

38) 明治期における伊東の設計活動については、拙稿「伊東忠太の最初期の 創作活動について - 明治期の図面類にみる伊東忠太の設計活動 その1」 (『日本建築学会計画系論文集』第558号、2002年 8 月)、「伊東忠太の西本 願寺関連の計画について - 明治期の図面類にみる伊東忠太の設計活動 その2」(「日本建築学会計画系論文集」第566号、2003年4月)。

(2003年 7 月 10 日原稿受理， 2003 年 9 月 19 日採用決定 